\title{
A STUDY ON STUDENTS' UNDERSTANDING ON APPLYING DECLARATIVE SENTENCE
}

\author{
Destina Kasriyati $^{1)}$, Ajah Rosidah ${ }^{2)}$, \\ ${ }^{1}$ English Education Department, Universitas LancangKuning-Pekanbaru, Riau \\ email: destina@unilak.ac.id \\ ${ }^{2}$ English Education Department, Universitas LancangKuning -Pekanbaru, Riau \\ email: ajahrosidah@gmail.com
}

\begin{abstract}
The purpose of the research was to find out students' understanding in writing declarative sentence based on sentence structure. Type of this research was survey design. Based on the research result students' understanding on applying declarative sentence was categorized into Fair. It meant that some students had understood about declarative sentence based on their written and almost students found problem that they got difficult in writing declarative sentence in position subject and verb in test form. Therefore, to solve the problem, the teacher should gave materials clearly and find out the strategies to make interesting learning and gave more exercises.
\end{abstract}

Keywords: Declarative Sentence, Sentence Structure, Understanding.

\section{INTRODUCTION}

An English is as internasional language in the world, it is used as world language communication to people. When indonesian people come to overseas, they should be able to use an English as their communication. Nowdays English is very important thing because not only for communication but also English as language of instruction in products. Therefore an English is a language that is mostly spoken by most people, because English provides many opportunities that allow us to communicate or adapt easily to many people between countries. By mastering English, we can get anInternational career level. Then when we look at various kinds of technology today, we will definitely find English in it, now mastering English can also help us understand technology properly and correctly.

English also has patterns and rules, therefore, in learning English we need to know English grammar. By understanding grammar, English students can build a sentence

Creation is distributed under the Creative Commons License Attribution-Share Alike 4.0 International

Published in: http://ejournal.stkipmpringsewu-lpg.ac.id/index.php/smart Jurnal SMART : Journal of English Language Teaching and Applied Linguistics. 
properly and correctly. The level of one's English language knowledge is seen from how well he can master grammar. The most of the English students around us have problems in learning a lot of grammar with grammar formulas, and then students find it difficult and bored to learn grammar.

Sentence is a group of words containing subject and verb and takes complete meaning, there are four kinds of sentence. They are: Statement (declarative), command (imperative), question and exclamation. Based on English national curriculum of Kurikulum Tingkat Satuan Pendidikan(KTSP) in the standard of competence of speaking and writing in the eighth grade of the first semester, declarative sentence has been written. Teaching declarative sentence has been writing in English national curriculum in eighth grade students of MTsPon-Tren Ni'matullah Tapung Hulu in standard of competence of speaking and writing. The students are expected to be able to make a good sentence in declarative sentence. As descriptive text included in the English Language curriculum in Indonesia (Ministry of Education and Culture, 2013) states that knowing how the text should ideally be arranged is important for the teacher as a person responsible for delivering it in class and for students which is required to master it.

By understanding declarative sentence students can write the good text of statement or opinion and can make the readers understand about the statement. Based on the observation of researcher in MTs Pon-Tren Ni'matullah class VIII about declarative sentence, the researcher found several students had problems when using declarative sentence; students felt difficult in understaning and writing declarative sentence based on sentence structure.

Declarative sentence is one of kinds of the sentence which is used to give the statement or opinion, this sentence is often used by people in daily life. When the students can understand about declarative sentence correctly, the students can make the statement or information correctly especially in writing. Declarative sentence will also be found on a news, sheet, magazine, and novel. If you do not understand about declarative sentences then you will not understand the intent and core in the text that you read, the declarative sentence has also been researched by several researchers, such as, Wujisguleng (2011) entitled "Intonational Comparison Between Declarative and Interrogative Sentences in Mongolian" In Mongolian, declarative and interrogative sentences differ in following aspects: firstpitch contour of declarative sentence is generally declined while in 
Destina..

interrogative sentences, pitch contour goes up from the middle of a sentence, goes down sharply and goes up again at the end of a sentence, or continue to rise and goes down in the end; second, declination of pitch contour in declarative sentences is larger than that in interrogative sentences; third in declarative sentences pitch threshold decline and voice range narrows gradually while in interrogative sentences, pitch threshold changes less and voice range expands evidently in the end of a sentence; fourth at the beginning of a sentence, intonation width in declarative sentence is less than that in interrogative sentence; fifth, declarative sentence, in the middle part of a sentence, the upper and lower intonation of intonation range decline sharply while for interrogative sentence, the upper intonation of intonation range declines sharply but lower intonation declines moderately; the sixth, intonation range of the end of a sentence in declarative sentence is narrower than that in interrogative sentence; seventh, for declarative sentence, the whole intonation range of declarative sentence gradually narrow while for interrogative sentence, intonation range narrows from the middle part and expands in the sentence final. Based on the result research above that declarative and introgative sentence result could be different from seven aspects, while in our result result that findings could see from written test.

Fujisaki and Hirose (1984) entitled "Analysis of natural utterances of various declarative sentences of Japanese" revealed that the model can generate close approximations to observed F0 contours from a set of discrete commands and a small number of parameters. The extracted parameters were found to be closely related to linguistic factors and factors constituting the naturalness of speech. These results provide a means for generating natural F0contours from a small set of parameters and rules for synthesis. Anita Kusumawati (2009) research entitled "Contrastive Analysis between Indonesian and English Declarative Sentences", The aim of her research is to find out the differences and similarities of declarative sentences in two languages, namely in Indonesian and English. Faris and Cheng (2009) research entitled "Understanding and Executing a Declarative Sentence Involving a Forms of 'Be' Verb". The aim of this paper is to discusstwo grammatical components that influence sentence understanding: roles and controls. Heri Kuswoyo (2014) research entilted "Declarative Sentence Pattern In "Laskar Pelangi" and "The Rainbow Troops": A Translation Study of Indonesian To English".This research discusses about the differences and similarities of declarative sentence between Indonesian novel and English translation novel. 
According to Faris, \& Cheng (2009) in their result research that recognized all the potential effects when it is given a declarative sentence involving an action the result were three major bodies of knowledge that need to be learned. The first body of knowledge is the English grammar. The second body of knowledge involves each individual action. The last body of knowledge acts as a bridge between the English grammar and actions. The researcher just to recognized intention of a sentence, especially a sentence involving cause and effects, is an important first step for a program to perform logical reasoning. ObjectOriented paradigm is used to analyze the problem and design the solution attacking the problem.

On the other hand, according to Gao et al (2011) conducted a research about simulation process of chinese simple negative declarative sentences and test "Two step Simulation Hypothesis". Their research used experimental research design. Experimental class used simulation of Chinese simple negative declarative sentences on Pentium III computer, using E-Prime software. While the control group class used pictures as the contracdictory states described by the sentences, which composed matched and mismatched condition for sentence -picture pair. The result of experiment 1 that the response time of matched state was shorter that mismatched state significanly in both affirmative and negative sentences. In experiment 2 there was significant difference between mathced and mismatched state. So the simulation of actual state of affair can be achieved at the initial period.

Tursun et al (2011). Undulating scale of the intonation of declarative sentences in Uyghur. This research indicated that there overall intonation can be divided into sub domain intonation to identify the rising or falling pitch contours to analyze sentence level intonations. The intonations between different persons can be compared and the distribution characteristics of pitch contours of declarative sentence can be identified. The different research seen from kind of research data, it was spoken data but in our research was written data.

One of the researcher of declarative sentence suggested for researching declarative sentence based on sentence structure. Sentence structure is the way to arrange the sentence by using noun and verb fall within an indiviual sentence. Based on the explanation above, the researchers were interesting knowing the effort to improve students' understanding in 
Destina..

using declarative sentences entitled “A Study on Students' understanding on Applying Declarative Sentence".

\section{RESEARCH METHOD}

The design of this research was quantitative research design. Creswell (2005) defines that survey design was procedure in quantitative research in which investigators administer a sample or to the entire population of people in order to describe the attitudes, opinions, behaviors, or characteristic of the population. In this research, the researcher collected the data by using test and statically analyzed the data to describe about the answer of research question or hypothesis.

This research was conducted on18 March 2019, at the eighth grade students of MTs Pon-Tren Ni'matullah Tapung Hulu in academic year 2018/2019. The population of this research consisted of three classes. They were class VIIIA consisted15 students, class VIIIB consisted15 students and class VIIIC consisted of 30 students. Total students were 60.The sample of the research was taken by usingtotal sampling.

In this research, the instrument was test; the test was 25 exercises, 14 declarative sentences in affirmative by using present continuous verb and 11 declarative sentence in negative by using present continuous verb. To collect the data, firstly the researchers came to class and explained about how to answer this questions, then separated some worksheet papers. Therefore students got the worksheet paper,then students answer the question carefully. The researchers gave a chance about one hour to answer all the questions. Then when the students finished their test, it was collected. The result of the data then was analyzed by using formula. The formula as follow:

To analyze the data, the researchersused descriptive analysis, as present below:

Mode : The most frequently occurring scores.

Median: The middle of a set score.

$$
\text { Mean }=\frac{\sum \text { Rawscores }}{\mathbf{N}}
$$

$\operatorname{Variance}\left(\mathbf{S D}^{2}\right)=\frac{\sum(\text { Rawscores }-(\text { mean }))^{2}}{\mathbf{N}}$

Standard Deviation $=\sqrt{\text { variance }}$

Z-score $=\frac{\text { Rawscores }- \text { Mean }}{\text { SD }}$ 
A study on students' understanding

Range: The difference between the highest and the lowest scores to items on an instrument. (Maximum-Minimum)

\section{FINDINGS AND DISCUSSION}

The researchch was done the real test on March, $18^{\text {th }} 2019$ to 60 participants at the eighth grade students of MTs Pon-Tren Ni'matullah Tapung Hulu. The test was given to answer the research question in this research. The research question was "How is the students' understanding in writing declarative sentence at the eighth grade students of MTs Pon-Tren Ni'matullah Tapung Hulu based on sentence structure"? In order to answer this question, the researcher instructed to the students to fulfill the test. The option test was twenty five questions, separated fourteendeclarative sentences in affirmative and eleven declarative sentences in negative.

There are 60 (sixty) students who have participated the test and has given the best answer. There were three students got score 16, there were two students got score 24 , there were two students got score 28 , there were two students got score 32 , there was one student got score 44 , there was one student got score 48 , there was one student got score 52 , there was one student got score 60 , there were four students got score 64 , there were three students got score 68, there were three students got score 72, there were eight students got score 76 , there were three students got score 80 , there were three students got score 84 , there were three students got score 88 , there were seven students got score 92 , there were four students got score 96, there were nine students got score 100.The total score (Sum) is 4.388and then divided into sixty participants equal 73.13 (mean) score of the students' understanding on applying declarative sentence.

It could be identified by related to school's range score that the students' understanding on applying declarative sentencewas categorized into Fair.

In this research, the researcher focused on declarative sentence based on sentence structure and based on school's syllabus the declarative sentence focused on present continuous tense form in affirmative and negative sentence.

\section{a. Central Tendency}

a) Mean : to calculate the mean of the score was presented below :

$$
\text { Mean }=\sum \underline{\text { Raw Score }}=\underline{4388}=73.13
$$

$\mathrm{N}$ 60 
Destina..

b) Mode : to know the mode of the score, the researcher looked at the most occurs score. The mode of the result was 100

c) Median : in analyzing the median, the researcher found the middle score was 76

d) Range : Range was found by maximum-minimum. The range score was 84

\section{b. Variability}

a) Variance : Variance gotten from calculation below

$$
\text { Variance }=\sum(\text { Raw Score }-M)=36899=614.98 \quad \mathrm{~N}=60
$$

b) Standard Deviation was 25

\section{c. Relative Standing}

a) Z-Score could be seen by following the formulation below :

Z-Score $=$ Raw score-mean

SD

b) Percentile

Percentile Rank can be seen by following the formulation below :

$$
\mathrm{R}=\mathrm{P} \% \mathrm{X}(\mathrm{N}+1)
$$

In accordance with the data analysis done during this research, the researcher found that the students' understanding on applying declarative sentence was categorized into Fair.

Based on the presentation and analysis of the research data above, the finding of the whole participants (60 students) led the researcher to infer that the students' understanding on applying declarative sentenceat the eighth grade students of MTs Pon-Tren Ni'matullah Tapung Hulu was categorized in to fair. It is because the average (mean) of the students' score was 73,13 . There were many students got high scores. As showed by table 5, most frequent score occurs was 100. In other words, many students got scores above60 (48 students) and only 12 students got under 60 . Variance of the students score was 625,4 and Standard Deviation was 25 . The scores range from a low of 16 to a high of 100 , range was 84 points. Variance and standard deviation were used to measure the variety of the data. The researcher found that the students still have problem in writing declarative sentence. Many of them can make declarative sentence based on sentence structure, but few of them 
A study on students' understanding ........

did not understand yet in making declarative declarative sentence based on sentence structure. They did not yet write the suitable sentence between subject and verb. So, the teacher should gave materials clearly and find out the strategies to make interesting learning, it is line with Gae et al (2011) and teacher have to give more exercises in order to students master English grammar, as Faris and Cheng (2009) stated that mastering english grammar and action is required in learning declarative sentence.

\section{CONCLUSION}

After conducting the research on problem faced by the students in writing declarative sentence based on sentence structure in present continuous tense in affirmative and negative sentence, the researcher found some students have understood about declarative sentence based on sentence structure and the researcher also found the problem faced by some students: they got difficult in writing declarative sentence in position subject and verb in test form. In accordance with the data analysis done during this research, the researcher concluded some students had understood about declarative sentence based on sentence structure and some of them did not understand yet about declarative sentence.The researcher found that the students' understanding on applying declarative sentence was categorized into Fair.

\section{REFERENCES}

Ahn, E., Faris, W., \& Cheng, K. H. (2009, February). Recognizing the Effects Caused by an Action in a Declarative Sentence. In IC-AI, pp. 149-155.

Anita, Kusumawati. (2009).Contrastive Analysis Between Indonesian And English Declarative Sentence. Jakarta: Tarbiyah and Teachers Training Syarif Hidayatullah State Islamic University.

Creswell, W. John. (2005). Educational Research Planning, Conducting, and Evaluating Quantitative and Qualitative Research. Second Edition. USA: University of Nebraka- Lincoln.

Faris, W., \& Cheng, K. (2009). Understanding and Executing a Declarative Sentence involving a forms-of-be Verb. In 2009 IEEE International Conference on Systems, Man and Cybernetics,pp. 1633-1638. 
Destina..

Fujisaki, H., \& Hirose, K. (1984). Analysis of voice fundamental frequency contours for declarative sentences of Japanese. Journal of the Acoustical Society of Japan (E), 5(4), 233-242.

Gao, Z. H., LU, Z. Y., \& Ma, H. X. (2011).The simulation process of Chinese simple negative declarative sentence. Acta PsychologicaSinica. 43(12), 1380-1387.

Heri, Kuswoyo. (2014). Declarative Sentence Pattern In "Laskar Pelangi" And "The Rainbow Troops": A Translation Study of Indonesian To English. Bandung: English Linguistics, Faculty of Humanities Universitas Padjadjaran.

Tursun, D., Ali, G., Dagut, R., \& Hamdulla, A. (2011).Undulating scale of the intonation of declarative sentences in Uyghur. Journal of Tsinghua University Science and Technology. 51(9), 1191-1195.

Wujisguleng, I. M. U. H. (2011). Intonational Comparison between Declarative and Interrogative Sentences in Mongolian. Journal Philoshopy and sosial science. 3(2), $12-21$. 